ГАЄВИЙ В.В.

\title{
СПЕЦАЛЬНИЙ ПОРЯДОК ВІДШКОДУВАННЯ МОРАЛЬНОЇ ШКОДИ, ЗАВДАНОЇ ПОРУШЕННЯМ ТРУДОВИХ ПРАВ
}

Стаття присвячена вивченню правового змісту спеціального порядку відшкодування моральної шкоди, завданої порушенням трудових прав за законодавством України. Особлива увага приділяється аналізу стадій розгляду справи про відшкодування моральної шкоди працівнику комісіями із трудових спорів та строків відшкодування моральної шкоди працівнику на підставі відповідного рішення коміciï. Наголошено, що в тих випадках, коли роботодавець ігнорує рішення комісії із трудових спорів, в яких його зобов'язують відшкодувати працівнику завдану ним моральну шкоду у визначеному в рішенні розмірі, і він не виконує таке рішення у встановлений термін, комісія видає працівникові посвідчення, що має силу виконавчого листа. Зроблено висновок, що спеціальний порядок відшкодування моральної шкоди працівнику виражений у спеціальній формі відшкодування такої шкоди і розкривається у процедурах вирішення трудового конфлікту комісією із трудових спорів, що відбувається за заявою працівника, яка була вчасно подана працівником до комісії після невдалого врегулювання розбіжності під час безпосередніх переговорів із власником (чи уповноваженим ним органом) і прийнята комісією, в результаті чого комісія зобов'язується протягом десяти днів вирішити справу. За цей період комісія може викликати свідків (неявка свідків, як і відмова від показань чи дання неправдивих показів, не тягне ніякої відповідальності для таких), доручати фахівцям проводити фахові перевірки, вимагати від власника надати комісії необхідні документи (ігнорування роботодавцем таких вимог комісії не зумовлює його відповідальність), а працівник і роботодавець, у свою чергу, можуть заявляти мотивований відвід будь-якому члену комісії, що вирішується більшістю голосів членів комісії, присутніх на засіданні. Дослідивши матеріали справи та доводи сторін, комісія приймає рішення, яке може бути оскаржене в суді, а якщо таке не оскаржується, рішення набирає законної сили і повинне виконуватись сторонами. Якщо роботодавець не виконує рішення комісії в добровільному порядку, працівнику видається посвідчення, яке має силу виконавчого листа.

Ключові слова: відикодування моральної шкоди, моральна шкода, спеціальний порядок відшкодування, трудові права, трудові правовідносини.

The article is devoted to the study of the legal content of the special procedure for compensation of moral damage caused by violation of labor rights under the laws of Ukraine. Particular attention is paid to the analysis of the stages of consideration of the case of compensation for non-pecuniary damage to the employee by the commissions on labor disputes and the terms of compensation for non-pecuniary damage to the employee on the basis of the relevant decision of the commission. It is emphasized that in cases where the employer ignores the decision of the commission on labor disputes, in which he is obliged to reimburse the employee for non-pecuniary damage in the amount specified in the decision, and he does not comply with such a decision within the prescribed period, the commission issues a certificate has the force of a writ of execution. It is concluded that the special procedure for compensation for non-pecuniary damage to the employee is expressed in a special form of compensation for such damage, and is disclosed in the procedures for resolving labor disputes by the Labor Disputes Commission. negotiations with the owner (or his authorized body) and accepted by the commission, as a result, the commission undertakes to resolve the case within ten days. During this peri-

(C) ГАСВИЙ В.В. - здобувач кафедри правознавства (Східноукраїнський національний університет імені Володимира Даля) 
od, the commission may call witnesses (absence of witnesses, as well as refusal to testify or giving false testimony does not entail any responsibility for such), instruct experts to conduct professional inspections, require the owner to provide the commission with the necessary documents (ignoring such requirements by the employer does not responsibility), and the employee and the employer, in turn, may declare a reasoned dismissal to any member of the commission, which is decided by a majority vote of the members of the commission present at the meeting. After examining the case file and the arguments of the parties, the commission makes a decision that can be appealed in court, and if it is not appealed, the decision takes effect and must be enforced by the parties. If the employer does not comply with the decision of the commission voluntarily, the employee is issued a certificate, which has the force of a writ of execution.

Key words: compensation for moral damage, moral damage, special procedure for compensation, labor rights, labor relations.

Вступ. Метою статті є дослідження спеціального порядку відшкодування моральної шкоди, завданої порушенням трудових прав за законодавством України. Актуальність обраної теми $\epsilon$ очевидною з огляду на два чинники: по-перше, до сьогоднішнього дня в доктрині трудового права комплексно не досліджувалося питання судового порядку відшкодування моральної шкоди, заподіяної порушенням трудових прав, що $є$ неприпустимим, головним чином, з огляду на реальні можливості працівника оптимально захистити свої права в комісії із трудових спорів і деякі бар'єри, які передбачені законодавством для працівників, що бажають звернутись до цієї форми захисту. Дане дослідження націлене на вирішення цього питання, що, безумовно, сприятиме і кращому теоретичному розумінню питань спеціальної форми відшкодування моральної шкоди та оптимізації захисту права працівника на отримання відшкодування такої шкоди на практиці. По-друге, зважаючи на те, що в нашій державі досі триває реформа законодавства про працю, яка, серед іншого, передбачає прийняття проекту ТК України, вбачається необхідною детальна регламентація в новому кодексі питання спеціального порядку відшкодування моральної шкоди, завданої порушенням трудових прав, зважаючи на вимоги сучасності і потреби в оптимізації захисту зазначеного права працівника.

Сприятиме досягненню поставленої мети у процесі наукового пошуку звернення до суміжних галузей права, аналіз точок зору спеціалістів, науковців із цього питання (П.А. Бущенко, А.М. Слюсар, В.Д. Чернадчук, Н.М. Швець), вивчення положень нормативно-правових актів.

Результати дослідження. Спеціальна форма відшкодування моральної шкоди виражається в процедурах вирішення трудового конфлікту комісією із трудових спорів. При цьому особливістю розгляду трудового спору в комісії $€$ те, що такий спір відповідно до ч. 2 ст. 224 КЗпП України підлягає розгляду в комісії із трудових спорів лише за умови, що працівник самостійно (або за участі профспілкової організації, яка представляє його інтереси) не врегулював розбіжності під час безпосередніх переговорів із власником чи уповноваженим ним органом. Іншими словами, працівник, перш ніж звернутися в комісію із трудових спорів, зобов'язаний ужити відповідні заходи 3 урегулювання розбіжностей, що виникли, безпосередньо обговоривши ситуацію 3 роботодавцем. Якщо працівник таких заходів не вжив, комісія вправі відмовити йому у прийнятті та розгляді його заяви. Однак і в такому випадку, як зазначають П.А. Бущенко, А.М. Слюсар та H.M. Швець, працівник може звернутися із заявою про розв'язання трудового спору безпосередньо до суду, оскільки там жодних попередніх процедур для врегулювання трудових спорів законодавством не передбачено [1, с. 24].

Відтак для того щоб реалізувати своє право на відшкодування моральної шкоди в порядку вирішення такого спору комісією із трудових спорів, працівник-потерпілий повинен спершу подати до комісії відповідну заяву. Слід зазначити, що чинне законодавство про працю не містить певних стандартів та правил щодо змісту і форми такої заяви, однак, зважаючи на ч. 3 ст. 225 КЗпП України, можна зробити висновок, що заява працівника, яка надійшла до комісії, підлягає обов'язковій реєстрації, а отже, має бути оформлена письмово. За своїм змістом, на думку П.А. Бущенко, А.М. Слюсар та Н.М. Швець, заява має відповідати загальним вимогам щодо документів такого роду і з огляду на це повинна містити: назву комісії із трудових спорів; дані про працівника, що подає заяву (прізвище, ім'я, по батькові, посада, домашня адреса, номер телефону); відомості про представника, якщо таку заяву подає представник; зміст вимог та викладення обставин, якими працівник обгрунтовує вимоги із зазначенням доказів, що підтверджують ці обставини; перелік документів, що додаються до заяви [1, с. 25]. 
Перед тим як працівник буде подавати заяву до комісії із трудових спорів, він повинен вирахувати, чи не пропустив він строки звернення до комісії. Так, слід мати на увазі, що відповідно до чинного законодавства комісії уповноважені розглядати трудові спори щодо захисту трудових прав працівників, які звернулися не пізніше трьох місяців із дня, в який їм стало відомо або вони повинні були дізнатися про порушення свого права (крім спорів про виплату належної їм заробітної плати, які не обмежуються в часі). Тобто якщо працівник має бажання звернутись до порядку захисту свого трудового права на відшкодування моральної шкоди шляхом процедури вирішення трудового конфлікту комісією із трудових спорів, таке звернення у формі заяви не повинно бути поданим пізніше трьох місяців після того, як працівник дізнався чи повинен був дізнатись про порушення роботодавцем відповідного його трудового права.

Що ж стосується безпосереднього порядку і строків розгляду трудового спору в комісії із трудових спорів, то слід зауважити, що такий порядок характеризується помітною оперативністю вирішення трудового спору: після того як комісія отримала відповідну заяву працівник-заявника, вона зобов'язана в десятиденний строк із дня подання такої розглянути трудовий спір із приводу захисту права працівника на відшкодування моральної шкоди.

Такі спори повинні розглядатися у присутності працівника, який подав заяву (розгляд за його відсутності допускається лише за письмовою заявою заявника), представника працівника (якщо заявник бажає, щоб його інтереси у спорі представляв представник профспілкового органу, правозахисник, адвокат чи інша особа із спеціальними знаннями, незважаючи на те, чи присутній сам працівник, чи ні - такий представник повинен допуститись до процедури вирішення спору), а також представників власника або уповноваженого ним органу.

Якщо працівник або його представник не з'явився на засідання комісії, розгляд заяви відкладається до наступного засідання, але і в цьому випадку комісія зобов'язана додержуватися десятиденного терміну, встановленого для розгляду заяв працівників. Такий висновок, на думку П.А. Бущенко, А.М. Слюсар та Н.М. Швець, випливає зі змісту ч. 1 ст. 226 КЗпП України, яка зобов'язує комісію розглянути трудовий спір у десятиденний строк із дня подання заяви і не передбачає жодних винятків. Разом із тим учені зазначають, що на практиці розгляд заяви в десятиденний строк не завжди можливий і часто порушується, наприклад, через відкладення засідань комісії, відсутність кворуму, а також те, що члени комісії із трудових спорів найчастіше не $\epsilon$ професійними юристами, і їм потрібно значно більше часу, щоб з'ясувати суть спору та вивчити положення законодавства, які застосовуються для його вирішення. Водночас через порушення комісією із трудових спорів установленого терміну розгляду заяв не можна ставити під сумнів правомірність ухваленого цією комісією рішення. Якщо працівник без поважних причин повторно не з'явився і не подав відповідної заяви про розгляд справи за його відсутності, комісія може винести рішення про зняття цієї заяви з розгляду, але це не позбавляє працівника права подати iii знову в межах тримісячного строку із дня, коли він дізнався або повинен був дізнатися про порушення свого права [1, с. 27-28].

Процедура розгляду справи комісією законодавчо не врегульована, проте на практиці вона ззовні нагадує спрощений судовий процес, який має місце в судах загальної юрисдикції: комісія може викликати свідків (неявка свідків, як і відмова від показань чи дання неправдивих показів, не тягне ніякої відповідальності для таких), доручати фахівцям проводити фахові перевірки, вимагати від власника надати комісії необхідні документи (ігнорування роботодавцем таких вимог комісії не зумовлює його відповідальність); працівник і роботодавець можуть заявляти мотивований відвід будь-якому члену комісії, що вирішується більшістю голосів членів комісії, присутніх на засіданні; здійснюється ведення протоколу засідання комісії (порядок ведення такого протоколу не врегульовано законодавством), який, як правило, веде секретар комісії.

Що стосується питання розгляд трудового конфлікту комісією із трудових спорів, то такий розгляд складається з таких двох стадій [2, с. 11]:

1) встановлення факту заподіяння моральної шкоди. У процесі підготовки та розгляду спору комісія, зважаючи на зміст ч. 3 ст. 226 КЗпП України, уповноважена здійснювати всі законні дії, необхідні для всебічного та об'єктивного розгляду й вирішення спору. Так, як вже зазначалось, комісія може: викликати на засідання свідків, доручати спеціалістам проведення технічних, бухгалтерських та інших перевірок, вимагати від власника або уповноваженого ним органу необхідні розрахунки й документи;

2) визначення розміру і строків відшкодування в рішенні комісії. Визначення розміру моральної шкоди відбувається в залежності від глибини завданої моральної шкоди, яку можуть охарактеризувати не лише працівник-заявник та його свідки, але й фахівці-медики. При цьому, 
надаючи своїм висновкам по суті справи юридичної сили, комісія оформлює їх як підсумковий документ - рішення комісії. Так, зважаючи на зміст ст. 227 КЗпП України, можемо зробити висновок, що комісія приймає рішення у справі більшістю голосів ії членів, присутніх на засіданні. У такому підсумковому документі зазначаються: 1) повне найменування комісії із трудових спорів (виходячи з найменування підприємства чи структурного підрозділу); 2) прізвище, ім'я та по батькові працівника-заявника та його представника (за наявності); 3) дата звернення до комісії і дата розгляду спору; 4) коротка суть спору; 5) прізвища членів комісії та головуючого, секретаря комісії 6) прізвище власника або представників уповноваженого ним органу; 7) результати голосування комісії; 8) мотивоване рішення комісії.

Після того як комісія прийняла власне рішення у справі, вона зобов'язана вручити у триденний строк копії такого рішення працівнику-заявнику та власнику (або уповноваженому ним органу).

Що стосується питання строків відшкодування моральної шкоди працівнику, то слід звернути увагу на те, що за загальним правилом, яке міститься у ст. 229 КЗПП України, рішення комісії підлягає виконанню власником або уповноваженим ним органом у триденний строк після закінчення десяти днів, передбачених на його оскарження. При цьому законодавець передбачає і винятки із цього правила, однак вони не стосуються питання відшкодування моральної шкоди, завданої працівнику роботодавцем у рамках трудового права (виняток: поновлення на роботі незаконно звільненого або переведеного на іншу роботу працівника повинно відбуватись негайно).

Слід звернути увагу на те, що в тих випадках, коли роботодавець ігнорує рішення комісії iз трудових спорів, в яких його зобов’язують відшкодувати працівнику завдану ним моральну шкоду у визначеному в рішенні розмірі, і він не виконує таке рішення у встановлений термін, комісія видає працівникові посвідчення, що має силу виконавчого листа.

Отримавши таке посвідчення, працівник, який бажає отримати компенсацію моральної шкоди, яку йому завдав роботодавець, повинен не пізніше тримісячного строку передати такий документ до районного (чи міського (міста обласного значення), районного у місті) відділу державної виконавчої служби, в якому вже на підставі п. 5 ст. 3 Закону України «Про виконавче провадження» від 21 квітня 1999 року № 606-XIV таке посвідчення підлягає виконанню державним виконавцем у примусовому порядку.

Окрім того, слід звернути увагу на те, що рішення комісії із трудових спорів може бути оскаржене працівником або власником чи уповноваженим ним органом у суді в десятиденний строк із дня вручення їм виписки з протоколу засідання комісії чи його копії. Пропущення зазначеного строку допускається через поважні причини, за наявності яких суд може поновити строк і розглянути спір по суті (що стосується працівника, якому завдали моральної шкоди, то пропущення ним строку повинно розцінюватись відповідним органом за принципом пом'якшеного ставлення до пропущення строку на подання працівником заяви до комісії із трудових спорів, про що вже вище йшла мова). Поряд із тим, якщо суд дійде висновку, що поновлення строку неможливо (головним чином, через неповажність причини пропуску строку), на підставі ст. 228 КЗПП України суд може залишити заяву без розгляду, в результаті чого рішення комісії із трудових спорів залишиться в силі.

Таким чином, до переваг, що характеризують порядок розгляду трудових спорів у комісіях iз трудових спорів, можуть бути віднесені: розгляд трудових спорів безпосередньо за місцем їх виникнення; доступність звернення працівників; безпосередня участь працівників у вирішенні трудових спорів; законодавче визначення порядку провадження у трудових спорах; законодавче регулювання виконання рішень комісії із трудових спорів [1, с. 32].

Висновки. Отже, підводячи підсумок усьому вищевикладеному, слід зауважити, що спеціальний порядок відшкодування моральної шкоди працівнику виражений у спеціальній формі відшкодування такої шкоди і розкривається у процедурах вирішення трудового конфлікту комісією із трудових спорів, що відбувається за заявою працівника, яка була вчасно подана працівником до комісії після невдалого врегулювання розбіжності під час безпосередніх переговорів iз власником (чи уповноваженим ним органом) і прийнята комісією, в результаті чого комісія зобов' язується протягом десяти днів вирішити справу. За цей період комісія може викликати свідків (неявка свідків, як і відмова від показань чи дання неправдивих показів, не тягне ніякої відповідальності для таких), доручати фахівцям проводити фахові перевірки, вимагати від власника надати комісії необхідні документи (ігнорування роботодавцем таких вимог комісії не зумовлює його відповідальність), а працівник і роботодавець, у свою чергу, можуть заявляти мотивований відвід будь-якому члену комісії, що вирішується більшістю голосів членів комісії, присутніх 
на засіданні. Дослідивши матеріали справи та доводи сторін, комісія приймає рішення, яке може бути оскаржене в суді, а якщо таке не оскаржується, рішення набирає законної сили і повинне виконуватись сторонами. Якщо роботодавець не виконує рішення комісії в добровільному порядку, працівнику видається посвідчення, яке має силу виконавчого листа.

\section{Список використаних джерел:}

1. Бущенко П.А., Слюсар А.М., Швець Н.М. Трудові спори та порядок їх розгляду : навчальний посібник. Харків : Національний університет «Юридична академія України імені Ярослава Мудрого», 2013. 110 с.

2. Чернадчук В.Д. Відшкодування моральної шкоди при порушенні трудових прав : автореф. дис. ... к.ю.н., спеціальність : 12.00.05. - Трудове право; право соціального забезпечення. Київ, 2001. 14 с.

УДК 349.2

DOI https://doi.org/10.32844/2618-1258.2019.5-1.16

ІНШИН М.I.

\section{ТЕОРЕТИКО-ПРАВОВА ХАРАКТЕРИСТИКА ЗМІСТУ ПЕРЕВАГ ДИСТАНЦЙНОЇ ЗАЙНЯТОСТІ ПРАЦІВНИКІВ}

У статті проаналізовано специфіку сучасного стану дистанційної зайнятості працівників. Наведено науковий аналіз доктринальних джерел у досліджуваній сфері. Визначено переваги такої нестандартної форми зайнятості працівників. Наведено аргументацію змісту кожної із них. Наголошено, що сучасні технології дозволяють виконувати трудові обов'язки, не перебуваючи при цьому на чітко визначеному місці. При цьому працівник та роботодавець можуть перебувати постійно на зв'язку, і робота працівника може координуватись керівником навіть у таких умовах. Наступними важливими перевагами є можливість самостійного вибору місця та режиму роботи. Тобто особа, працевлаштована на умовах дистанційної зайнятості, має можливість постійно змінювати робоче місце відповідно до умов свого способу життя, самостійно обирає робочий час, а також час відпочинку. Визначено, що найважливішою перевагою дистанційної зайнятості є здійснення трудових функцій у віртуальному середовищі з використанням інформаційних та комунікаційних технологій. Завдяки інформаційним та комунікаційним технологіям постійно розширюється інтелектуальний потенціал суспільства, а також відбувається інтелектуалізація трудової діяльності, що дозволило значно полегшити як виробничі процеси, так і інші складники трудової діяльності людей. Також інформаційні та комунікаційні технології створили можливість здійснювати свої трудові функції, не перебуваючи на робочому місці. Для того щоб здійснювати свої трудові обов'язки, отримувати за це дохід та приносити користь суспільству, працівник може перебувати будь-де та у будь-яких умовах. У цьому контексті можливість використання інформаційних та комунікаційних технологій, на нашу думку, $\epsilon$ великою перевагою, яка, з одного боку, дозволяє працівнику перебувати у комфортних для нього умовах, а з іншого - забезпечує для роботодавця постійну комунікацію із працівником, не залежно від його місцезнаходження. Зроблено висновок, що дистанційна зайнятість працівників є надзвичайно потрібною формою трудових відносин в умовах ринкової економіки. Дистанційна зайнятість несе позитивні змі-

(C) ІНШИН М.I. - доктор юридичних наук, професор, заслужений юрист України, академік Національної академії правових наук України, завідувач кафедри трудового права та права соціального забезпечення (Київський національний університет імені Тараса Шевченка) 